\title{
Domestic Violence Against Women Amid COVID-19: A Study of Muslim Women Victims of Domestic Violence in Silchar Town
}

\author{
Sabina Begam Ahmed ${ }^{1 *}$ and Aditi Nath ${ }^{2}$
}

${ }^{1}$ Doctoral Research Scholar, Department of Social Work, Assam University, Silchar, Assam, India

${ }^{2}$ Assistant Professor, Department of Social Work, Assam University, Silchar, Assam, India

*Corresponding author: sabina.msw.aus@gmail.com

Received: 22 Sept., 2021

Revised: 27 Nov., 2021

Accepted: 13 Dec., 2021

\begin{abstract}
Domestic violence has been considered as a general wellbeing and common freedoms issue that principally influences ladies and youngsters around the world. A few nations including India have detailed a huge expansion in abusive behavior at home cases since the COVID19-incited lockdowns and physical removing measures were executed. Present study aimed to understand the factors aggravating domestic violence among Muslim women in Silchar town and the approaches they adopted to resolve domestic violence issues. Silchar is a town of the state Assam. The qualitative design of the study adopted a case study method to collect data as per objectives. The present study conducted five case studies. Married women having a minimum three years of matrimonial relationship have been considered for the study and they have been selected using snowball sampling technique. Interview guide has been adopted as the primary source of data collection. During the collection of data, the interview as well as observation method was administered. The secondary sources of data used in the study are (i) journals, (ii) reports, (iii) websites and scholarly articles, (iv) research papers. The study found that dowry; interference of relatives; husband's relation with other women; suspicious attitude of husband; infertility issues are the dominant factors of domestic violence among Muslim women which had effect on physical, mental, emotional health of the victim. Mutual discussion, support from external agencies, availing counselling sessions, consulting doctor, filing cases were some of the approaches adopted by the victims to resolve the issues related to domestic violence. In some cases such approaches yield positive results when some filed cases against the abusers in court.
\end{abstract}

Keywords: Domestic Violence, Women, COVID-19, Lockdown, Silchar, Assam 
The pandemic incited lockdown was a work to confine the spread of COVID in one manner however it has brought forth plenty of issues domestic violence against women is one of them. Studies conducted globally present the increased cases related to violence at home during this pandemic. There was an expansion in calls to the helplines offering domestic violence help in numerous nations since the flareup of COVID-19 which further drew the concerns of countries like China, France, Spain, Italy, and the United Kingdom (Taub, 2020). The initial phases of lockdown increased stress, disrupted the smooth functioning of social organizations, no earnings and lesser admittance to administrations heightened the danger of viciousness against ladies across the world. The circumstance turned out to be more terrible for the ladies when measures like social distancing were put into practice and individuals were urged to remain at home. As a result, women were more exposed to violence by their intimate partners at that time and the children sitting at home due to school closure had to experience inter-parental violence.

Brazil has reported a rise in domestic violence by $40 \%$ (Guardian, 2020). It has been claimed by the Government of Spain that in one region of Spain, the cases of domestic violence had climbed by $20 \%$ in the underlying relatively few days of the control period and the cases expanded by $30 \%$ after a week when the country asserted its first examples of COVID. A leading organization of the United Kingdom working on domestic violence detailed that the services of domestic violence helplines have expanded by $25 \%$ in the UK in the primary seven-day stretch of the declaration made for social separation and lockdown by the Government of the UK. During a similar period, it has been seen that there was a $150 \%$ increment in visits to the shelter site (BBC, 2020). The information delivered by the National Legal Services Authority (NALSA), in India, speedy expansion in instances of abusive behaviour at home has been noticed due to the cross country lockdown. The National Commission for Women has gotten 1477 objections of abusive behavior at home in the middle of March $25^{\text {th }}$ to May $31^{\text {st }}, 2020$.

Of which approximately 727 grievances were obtained through WhatsApp helpline number set up in April to give simple admittance to the ones who can't compose messages or send protests by post, could get help (The Hindu, June 15, 2020). Despite launching the WhatsApp helpline, it could not fetch a positive result as just 38\% of women of India own telephones and not many approach web availability which further made the stage blocked off to a greater part of ladies in the country, particularly rural ladies. Government officials working for the protection of women victims like protection officers, police, and other social organizations even couldn't visit sufferers considering restrictions put on physical interactions and police being the bleeding edge laborers were putting forth attempts to handle COVID-19. In this way, they could not broaden their assistance for the protection of victims effectively (Kumar and Arora, 2020). Therefore, women were seen to take support from within their immediate communities to get rid of domestic violence-induced problems. One type of community group that provides women this platform is the Gram Panchayat. Women approach the Panchayat thinking that its members have the power to intervene where there is an incidence of domestic violence.

In the light of this, the present study attempted to understand the factors aggravating domestic violence among Muslim women of Silchar Town and the approaches adopted by them for resolving issues leading to domestic violence. 


\section{Literature Review}

Violent behavior against ladies in India is an issue of cultural standards and financial reliance. Various types of gender-based brutality establish the truth of most young ladies and ladies' lives in India. The author is of the assessment that numerous ladies are fiercely treated by their close accomplices and they experience peacefully. At times, aggressive behavior at home prompts the demise of these ladies. (Prescila, M. 2014). The study on Domestic Violence against Women in Pakistan and its Solution from an Islamic Perspective, Tahir, M. (2017), stated that in Pakistani society and culture, savagery against ladies is viewed as a private family issue with no fitting spotlight on evaluation, mediation, and arrangements. Accordingly, ladies need to bear brutal demonstrations and segregation consistently because of the abuse of social traditions, social qualities, and strict standards. As indicated by the creator, the even-minded and adaptable nature of Islamic lessons gives sound establishments to the issues leading to violence at home in Muslim societies across the globe among aggressive behavior at home issues among Muslim social orders all over the planet. He believes that the viable execution of Islamic methodologies would be incredibly strong in checking and diminishing causes and factors driving toward abusive behavior at home in Pakistani society. The author underscores the need for individual and aggregate endeavors and the need for Islamic advising and direction for the perpetrator (man) and victim (lady) to restore their fitting relationship by considering the five standards, for example, "anticipation, security, early mediation, revamping the existences of casualty survivors, responsibility. A community-based crosssectional study conducted by Gebrewahd, T. et al. (2020) pointed towards deciding the occurrence of spouse brutality against regenerative age ladies in Northern Ethiopia during April - May 2020. The gathered information uncovered that the greater part were the survivors of mental brutality followed by physical and sexual savagery. Gama A. et al. (2021), inspect the event of aggressive behavior at home, related factors and help to look for at the time of pandemic in Portugal. The study has gathered information from 1062 respondents. It is viewed that a large portion of the respondents didn't look for help $(62.3 \%)$ feeling that outer help, at any rate, won't transform them. Just $4.3 \%$ of the casualties looked for police help. A cross-sectional survey on abusive behavior at home against Muslim wedded ladies during the COVID-19 Quarantine in Saudi Arabia, Alharbi, F. et al. (2021) wanted to review the change between the pre-and intra-pandemic inescapability of abuse in Saudi Arabia. An aggregate, 2254 members were interviewed for the review. It is found in the review that the pervasiveness of aggressive behavior at home was $25.4 \%$ before the pandemic and during the quarantine period it has fallen to $16.6 \%$. As to kind of brutality, of the $315(16.6 \%)$ ladies who suffered savagery since the restriction, the larger part i.e. $95.6 \%$ encountered numerous types of vicious maltreatment, $87.7 \%$ experienced mental viciousness, $37.9 \%$ from actual brutality, and $16.6 \%$ from sexual savagery. Of the gathering who encountered numerous types of viciousness, $120(39.9 \%)$ detailed an increment in the recurrence and saw the force of the brutality since the repression. A study on arising reactions carried out to forestall and react to savagery against ladies and kids in European part states of World Health Organizations during the COVID-19 pandemic: a checking survey of online media reports, Pearson S. et al. (2021) intended to investigate the procedures that state-run administrations and common society associations carried out to forestall and react to the expected ascent in viciousness against ladies during 
2019. The review uncovered that out of 53 parts states, 52 have attempted something like one measure to forestall brutality against ladies during a pandemic. 40 member states have detailed common society that drove intervention and reaction. Among various measures, the most widely perceived initiative was the utilization of media and online media to bring issues to light and expand helpline services to those women presented with violence.

The literature reflected that domestic violence cases have increased immensely during pandemic across the globe. However, some writings illuminated the decrease of domestic violence cases during the confinement period. Women are victims of numerous forms of violence. Practically every one of the investigations studied above, uncovered that physical and mental viciousness are the most widely recognized types of brutality against ladies. Studies found examining the role of Government, NGOs $\&$ civil society organisations for tackling the issue. When awareness, use of online platforms, and help line services were expanded to resolve the issues related to domestic violence than some studies proposed solutions from religious perspectives. But how far the referenced causes and problem solving approaches would be relevant to a woman living in Silchar town is an inquiry to be addressed. It is in this foundation the review has been intended to comprehend the encounters of the victims of domestic violence at home of Silchar town of Assam.

\section{Objectives}

To understand the factors aggravating domestic violence among Muslim Women of Silchar Town .

To know the approaches adopted by the Muslim women victims of domestic violence of Silchar town for resolving domestic violence issues.

\section{Methodology and Study Area}

The qualitative study design tries to comprehend the elements accountable for abusive behavior at home among Muslim women residing in Silchar town following the approaches embraced by them for settling the issues connected with it. Silchar is the second biggest city of State Assam. To achieve the objectives, the researcher conducted five case studies. Married women having a minimum of three years of matrimonial relationship have been considered for the study and they have been selected using the snowball sampling technique. The interview guide has been adopted as the primary source of data collection. During the collection of data, the interview, as well as the observation method, was administered. The secondary sources of data used in the study are (i) journals, (ii) reports, (iii) websites and scholarly articles, (iv) research papers.

\section{The case studies}

\section{Case history: 1}

The women respondent of 28 years got married on the $15^{\text {th }}$ of February 2016 to a man of 31 years. 
They were married according to Islamic rites. The respondent is currently in her $7^{\text {th }}$ month of pregnancy. After a few months of their marriage, the respondent fell prey to physical abuse on the issue of dowry. She was forced to bring money from her paternal house and she complied three times. During the pandemic, her husband has lost income opportunities and thus asked her to bring ₹ 70000 from her parents. She refused to do so and her father also denied meeting further monetary demands saying that his son-in-law will miss utilizing the money. Getting annoyed with the entire conversation the husband started abusing the respondent physically which included kick, slapping, beating that further aggravated sleep disorder, anxiety, depression of respondents. Knowing the situation, her cousin's sister once informed the respondent's father. Father made an honest effort to determine the issue through a shared conversation. However, the conversation couldn't yield any outcome. Observing no other choice, the dad needed to take his little girl back home and brought the issue under the notification of help giving office over the telephone. The officials had three sessions of telephonic conversation with the victim but could not convince the abuser to speak to them. According to the victim if the problem does not get resolved she will file a case against the abuser in court.

\section{Case Study: 2}

After spending three years of matrimonial life, the respondent decided not to stay with family members. According to her, the husband is constantly being fed misinformation by the in-laws which created an atmosphere of distrust between the couple. This further aggravated because the husband was more inclined to his family members than to support his wife. This increased the hardship of the wife as she was often insulted, sometimes in front of other family members, both verbally and physically. Being a graduate herself helped her in perceiving the matter and eventually, she decided to avail of family counseling. But when she tried to persuade her husband to meet the counselor she was accused by her in-laws of conspiring to take her husband to a psychiatrist to prove her husband as mentally unstable. That later increased her stress level and affected her mentally which compelled her to leave the house and undergo counseling sessions alone to ensure mental peace for herself. She thought of giving some time to her relationship and would try to solve the problem through mutual discussion.

\section{Case Study: 3}

After having thirteen years of married life the respondent found his husband in a relationship with another woman. His close relationship with the women disturbed the smooth functioning of the family and most importantly it was impacting the mental health of the children. Having four children the man wanted to remarry again which was very heartening for the wife. The respondent at her level tried to deal with the situation by making him understand the consequences of his decision. But he was very much sure of his decision and thus left the house. The respondent has brought the matter under the notice of the parents of both parties. When her father went to speak with her husband he attacked his father-in-law with an iron weapon. After that episode, he came back home and started beating his wife with an iron rod and wooden stick. He has caused disturbances to the victim in many ways. He pours water in the bed of the victim so that she gets disturbed sleep. Once he poured kerosene on the victim along with 
the minor children to burn them alive and it continued for years after years. He finally drove the victim out of the housekeeping children with him during the pandemic which killed the emotions of a mother and a wife. The victim is with her parents and filed a complaint against the abuser in district court.

\section{Case Study: 4}

A 27-year-old woman got married at the age of 23 following Muslim marriage rites. Her dedication towards academics made her a teacher of elementary education at the age of 24 . Initially, she was praised due to her success by the family members including her husband. But after a year she realized that her husband is putting forth some restrictions on her. She was not allowed to speak to anyone, not even with her parents. If she found speaking with her male colleagues or with any individual she had to face the wrath of her husband and be punished accordingly. The suspicious attitude of the husband has put her in a room under lock and key for several days and it has become a part of life for the respondent. Such cruel conduct established an awkward family climate which straightforwardly affected the psychological wellness of the respondent. Getting no news from the respondent for a quite long time her mother once visited her home. The respondent could not make her mother acquainted with the prevailing situation. But somehow mother could understand something wrong is going on seeing her facial expression. After a week again her mother visited her and forcefully took her back at the parental home. After staying two months with her parents she went back to her husband's house and consulted with a psychiatrist. The abuser is under medications.

\section{Case Study: 5}

The respondent had a love marriage in 2016. The husband is a government servant. She failed to conceive even after three years of marriage. Her husband and in-laws always blamed her for not having a child and reprimanded her for being barren. She thought to consult a doctor but the husband and in-laws never wanted her to consult the doctor. Her voice on the issue made her victim of physical and mental torture. Her husband used to beat her with a wooden stick, slap her, and threaten her almost every day with a note to remarry again, and if she creates any problem she will be killed. Such an insensitive act was weakening the victim from inside, as expressed. She wanted to avail medical advice through teleconferencing but she could not as her mobile was seized by mother in law. Somehow she could convey the fact to her parents through a neighbor. Her parents came and through discussion wanted to resolve the issue. But it did not yield any positive result. At last, the respondent had to file a divorce case.

The case studies highlighted the factors like (i) dowry (ii) interference of relatives (iii) husband's relation with other women (iv) suspicious attitude of husband (v) infertility issues are responsible for domestic violence among Muslim women of Silchar town. These elements detrimentally affected the physical, mental, and passionate strength of the person. Mutual discussion, support from external agencies, availing counseling sessions, consulting doctors, filing cases were some of the approaches adopted by the victims to determine the issues connected with domestic violence. Sometimes such methodologies yield positive outcomes when a few files cases against the victimizers in court. 


\section{DISCUSSION}

The case narratives uncover that domestic violence not just happens among couples in light of inter-caste or inter-religion marriage, habits, household responsibilities yet in addition for issues associated with emotions, external affairs, internal politics of family, dominating attitude of mother in law, the silent attitude of husband, monetary demands of husband to in-laws abuses the women. Beating by spouse and parents in law, slapping, kicking, utilizing a stick or some other weapon like the wooden piece, is normal to physical abuse while taking steps to remarry, threat to kill, relationship with different ladies, scolding for not having a child, dowry is the reasons for psychological mistreatment. Using slang words for women was a form of verbal abuse. Approaches that have been taken on by the women victims are temporary in nature. Though the domestic violence helpline numbers were introduced to reach the victims easily and provide support services yet in some cases the respondents could not reap the benefit of this helpline service due to certain limitations.

\section{CONCLUSION}

Domestic violence is a global issue and ways to deal with such issues need an in-depth study and analysis. Various examinations across the globe presented almost similar kinds of factors yet there would be specific factors depending on the class, culture and religion, and so on. The investigation made in the review in light of the findings portrays the sorry plight of the Muslim women of Silchar town. It is perceived that the Muslim women however a victims of domestic violence yet they are with a thought process to proceed with their relationship by addressing the matter through a shared conversation. In some extreme cases, only Muslim women think of filing cases to get equity. The study recommended having more awareness and discussion on family issues to keep away from couple conflict. More information dissemination would be needed with regards to the services given by the support-providing agencies. Comprehensive education ought to be given to the Muslim ladies so they feel sure to move forward with their own choices which would be valuable for the smooth working of the family.

\section{REFERENCES}

1. Alharbi, F.F., Alkheraiji, M.A., Aljumah, A.A., Eissa, M.A., Qasim, S.S. and Alaqeel, M.K. 2021. Domestic Violence against Married Women during the COVID-19 Quarantine in Saudi Arabia. Cureus, 13(5).

2. Arora, K. and Jain, S. 2020. Locked-down: Domestic Violence Reporting in India during COVID-19. Retrieved from https://www.oxfamindia.org/blog/locked-down-domestic-violence-reporting-india-during-covid-19.

3. Gama, A., Pedro, R.A., Carvalho, L.J.M., Duarte, V.G.E.A., Quintas, J., Matias, A.,...Dias, S. 2021. Domestic Violence during the COVID-19 Pandemic in Portugal. Port. J. Public Health, 38(suppl 1): 32-40.

4. Gebrewahd, T.G., Gebremeskel, G.G. and Tadesse, B.D. 2020. Intimate partner violence against reproductive age women during COVID-19 pandemic in northern Ethiopia 2020: a community-based cross-sectional study. Retrieved from https://reproductive-health-journal.biomedcentral.com/articles/10.1186/s12978-020-01002-w. 
5. Pearson, S., Butler, N., Yelgezekova, Z., Nihlén, A., Aguirre, I.Y., Quigg, Z. and Stöckl, H. 2021. Emerging responses implemented to prevent and respond to violence against women and children in WHO European member states during the COVID-19 pandemic: a scoping review of online media reports. Pearson I, et al. BMJ Open 2021; 11:e045872.Doi: 10.1136/bmjopen-2020-045872. Retrieved from https://pubmed.ncbi.nlm.nih.gov/33827844/

6. Prescila, S.S. 2014. Domestic Violence against Women in India: A Family Menace. Indian Journal of Applied Research, 4(12), Special Issue - 2014.

7. Sepali, G., Brenda, R. and Cristina, C. 2012. Violence against Women: An Exploration of the Physical and Mental Health Trends among Immigrant and Refugee Women in Canada. Hindawi Publishing Corporation Nursing Research and Practice Volume 2012, Article ID 434592, doi:10.1155/2012/434592. Retrieved from https:/www.hindawi. com/journals/nrp/2012/434592/

8. Tahir, M. 2017. Domestic Violence against Women in Pakistan and its Solution from an Islamic Perspective: A Critical and Analytical Study. https://papers.ssrn.com/sol3/papers.cfm?abstract_id=2986723

9. The Hindu, 2020. Records-sharp-spike-in-domestic-violence-Amid Lockdown, June 15. Retrieved from https://www.thehindu.com/news/national/ncw

10. Times of India, 2020. Domestic violence cases in India on the rise during lockdown. Retrieved from https:// timesofindia.indiatimes.com

11. UN Women, 2020. The Shadow Pandemic: Violence against women during COVID-19. Retried from https:// www.unwomen.org/en/news/in-focus/in-focus-gender-equality-in-covid-19-response/violence-againstwomen-during-covid-19. 